\title{
PERSPECTIVES OF INNOVATION IN SERBIAN FIRMS- EMPIRICAL EVIDENCE FROM AGRO-FOOD AND SOFTWARE INDUSTRY
}

\author{
Marija Mosurović Ružičič ${ }^{1}$, Đuro Kutlača ${ }^{2}$, Nenad Stanišićc ${ }^{3}$, Dušica Semenčenko ${ }^{4}$ \\ *Corresponding author E-mail:marija.mosurovic@pupin.rs
}

\begin{abstract}
A R T I C LE I N F O
A B S T R A C T

Review Article

Received: 24 October 2017

Accepted: 04 September 2018

doi:10.5937/ekoPolj1803171M

UDC 001.76:338.012(497.11)

663/664:004.4(497.11)

Keywords:

management, innovation

indicators, agro-food industry, software industry

JEL: Q16, 031,032.

Based on the available literature on theory of innovation and the data processed from the official research on innovation activities in Serbian firms, this paper shows different perspectives of usage of the innovation activities indicators. The results showed that firms involved in software sector are more innovative than firms in agrofood sector. On the basis of the research conducted in this paper, it is possible to draw conclusions which are significant to the management of enterprises in observed industries. According to these recommendations, innovative enterprises management could respond to problematic situation of business economy in the field of innovation management through adequate business strategies. Besides that, empirical research in innovative activities in Serbia in the two observed sectors yield a serious analytic framework to guide industrial policy and employ appropriate measures in order to improve national competitiveness based on knowledge.
\end{abstract}

(C) 2018 EA. All rights reserved.

\section{Introduction}

The increasing attention to the phenomenon of innovation is related to various factors. Some of them are a part of the economic discipline and some of them are related to increasing empirical perception of the importance of technological factors for the competitiveness and growth (Dosi, 1988). The innovation should be viewed in two dimensions at the same time, as a conceptual and as perceptive phenomenon. In fact, successful innovation is the result of systematic analysis and studies of all sources of innovation, but, it is essential that there is recognized need for it (Drucker, 2003).

1 Marija Mosurović Ružičić, Scientific associate, Institute Mihajlo Pupin, University of Belgrade, Volgina 15,11000 Beograd,+381 11677 4452,marija.mosurovic@pupin.rs

2 Đuro Kutlača, Scientific advisor, Institute Mihajlo Pupin, University of Belgrade, Volgina 15, 11000 Beograd, + 38111677 4452, djuro.kutlaca@pupin.rs

3 Nenad Stanišić, Associate professor, Faculty of Economics, University of Kragujevac, Djure Pucara Starog 3, 34000 Kragujevac, +381 34303 500,nstanisic@kg.ac.rs

4 Dušica Semenčenko, Scientific associate, Institute Mihajlo Pupin, University of Belgrade, Volgina 15,11000 Beograd, + 38111677 4452, dušica. semencenko@pupin.rs 
Differences in growth rates between industries are well known and quite obvious. Also, the fact is that growth rates in some industries are steadily decreasing, while some other industries show high intensity of growth. Most industries with high R\&D intensity appeared in the $20^{\text {th }}$ century, and recorded extremely high growth. Quite obvious was that high growth rates were associated with level of technological innovation as well as with high rate of diffusion of innovations within the global economy. The recognition of the growing role of science and production connections, as well as their empowerment is seen as a national development priority (Lundvall, 1988). The difference between the growth rates and productivity, in different industries, is systematically related to the R\&D intensity and the patterns of technical change. Industries with declining growth rates are generally characterized by low levels of R\&D intensity and low rate of technological change. However, the existence of a statistical relationship between technological progress and the industries growth does not necessarily mean that only technological innovation fosters the growth (Freeman, 1982). It does not mean that firms that are operating within the low technology intensive sectors achieved lower benefits from their innovations. The result of innovation activities are in line with numerous factors: market demand, customer requirements, competition, and suppliers. Integral part of research innovation performance involves investigating innovation activities. Within the circumstances of changing environment, the innovation is seen as new driver for development not only for the firms, but for whole regions (Gotz, 2015).

"An innovation is the introduction of a new or significantly improved product, process, organisational method, or marketing method by your enterprise. The innovation must be new to your enterprise, although it could have been originally developed by other enterprises" (OECD, 2005).

Significantly improved products and processes represent new combination of existing knowledge. Schumpeter's explained that the new combination of existing knowledge means bringing together two aspects of the innovation: existing elements and new elements (Lundvall et al., 2002). Innovation, in this sense, also means, change of economic structure, by introduction the new things and destruction of the old. But the new combination does not just mean technological changes; it highlights the importance of research and development for economic growth and underlines the importance of market power (Tunzelmann, 1995). Through empirical studies about innovation activities in firms, it is possible to create patterns of technological change.

Progress in the analysis of innovation activities at a firm's level has been achieved in the 90s by setting up of the Oslo Manuel and Community Innovation Survey's (CIS). Based on the analysis of data obtained by CIS questionnaire, it is possible to create indicators that can be used as a framework in order to describe innovation activities (OECD, 2005). Information about innovation activities is the main innovation input and CIS data can be used to describe innovation behaviour of firms in particular industries (Franconi \& Standler, 2002). Some studies explored motives and impacts of R\&D collaboration (Negassi 2004; Cassiman \& Veugelers, 2002). Also, some studies put attention on regional aspect as a factor of innovation activities (Copus et 
al., 2008; Franconi \& Stander, 2002;). Others assessed the implications of innovation activities for innovation policy (Aralica et al., 2008; Knell, 2008) while some point out organisational aspect of technological innovation (Mosurović \& Kutlača, 2011). The majority of studies were oriented in order to investigate relationship between R\&D and productivity (Mairesse et al., 2002; Knell, 2008).

According to the official national statistical reports (CIS reports), over the past decade, the total number of innovators in Serbia has shown a slight decline in almost all economic activities, except electricity, gas, steam and air conditioning supply and administrative and support service activities. Innovative firms are defined as those having introduced product or process innovation, innovation in organization or marketing innovation during the observed period. It has been noticed that the differences, in terms of share of innovative firms, are more perceptible between the sectors within the period, than between the observed periods themselves (Table 1).

Table 1. Innovation in Serbian firms by NACE classification (2008-2016)

\begin{tabular}{|l|l|l|l|l|}
\hline \multirow{2}{*}{ Indicators } & \multicolumn{4}{c|}{ Innovation (\%) } \\
\cline { 2 - 5 } & $\begin{array}{l}\mathbf{2 0 0 8}- \\
\mathbf{2 0 1 0}\end{array}$ & $\begin{array}{l}\mathbf{2 0 1 0} \\
\mathbf{2 0 1 2}\end{array}$ & $\begin{array}{c}\mathbf{2 0 1 2}- \\
\mathbf{2 0 1 4}\end{array}$ & $\begin{array}{c}\mathbf{2 0 1 4 -} \\
\mathbf{2 0 1 6}\end{array}$ \\
\hline Total & 47,9 & 44,6 & 40,5 & 41.2 \\
\hline Agriculture, forestry and fishing & 43,2 & 30,3 & 22,9 & 41.9 \\
\hline Mining and quarrying & 40,7 & 37,0 & 19,3 & 27.1 \\
\hline Manufacturing & 57,6 & 50,5 & 42,7 & 47.9 \\
\hline Electricity, gas, steam and air conditioning supply & 42,7 & 46,2 & 53,2 & 53.7 \\
\hline $\begin{array}{l}\text { Water supply; sewerage, waste management and remediation } \\
\text { activities }\end{array}$ & 38,6 & 32,5 & 35,1 & 31.1 \\
\hline Construction & 37,7 & 40,6 & 36,2 & 36.7 \\
\hline $\begin{array}{l}\text { Wholesale and retail trade; repair of motor vehicles and } \\
\text { motorcycles }\end{array}$ & 43,7 & 42,0 & 40,7 & 31 \\
\hline Transportation and storage & 37,9 & 34,4 & 31,7 & 37.3 \\
\hline Accommodation and food service activities & 37,5 & 42,6 & 46,2 & 30.8 \\
\hline Information and communication & 56,5 & 53,7 & 47,6 & 40.2 \\
\hline Financial and insurance activities & 66,9 & 72,1 & 36,3 & 38.1 \\
\hline Real estate activities & 36,1 & 24,4 & 26,9 & 8.5 \\
\hline Professional, scientific and technical activities & 51,0 & 50,6 & 37,5 & 47.3 \\
\hline Administrative and support service activities & 39,0 & 37,7 & 43,4 & 53.1 \\
\hline
\end{tabular}

Source: Statistical Office of the Republic of Serbia (2017). Indicators of Innovative Activities in the Republic of Serbia, 2014-2016, Release number 197. Statistical Office of the Republic of Serbia (2015). Indicators of Innovative Activities in the Republic of Serbia, 2012-2014,

Release number 276. Statistical Office of the Republic of Serbia (2013). Indicators of Innovative Activities in the Republic of Serbia, 2010-2012, Release number 285. Statistical Office of the Republic of Serbia (2011). Indicators of Innovative Activities in the Republic of Serbia, 2008-2010, Release number 347. 
In this paper software industry and agro-food were chosen to be analysed further as areas with high potential for Serbian economic development. The period 2008-2010 is observed because the complete data base was provided for this period. Innovation is seen as driver for agro-food sector in many industrialized countries that increase competitiveness of the whole sector (Adenle et al., 2017). It can be noted that the agro-food sector is gaining more and more importance in governmental policies which causes some improvements within its own area (strengthening legislation, sustainability, globalization, competition, climate change, public opinion, networking and collaboration, technological innovation) (Mulder, 2008). This sector is very wide and diversified, with different levels of R\&D intensity. Agro-food sector is seen as a sector with great potential for development in Serbian economy. But, in terms of sustainable growth rate, Serbia "does not sufficiently use all competitive advantage it has in agriculture and food industry" (Jović et al., 2016).

The software industry has been indicated as the most dynamic and fastest growing sector in Serbia in the last ten years (Živković et.al, 2018). The main specificity of the software sector is mostly shaped by its generic characteristics, which is an important feature that contributes to the rapid and wide diffusion of technologies in almost all industries, and thus the whole economy of certain countries. Evaluation of the innovation potential of companies in the software is a very challenging task because of the character of the software in terms of relatively low cost of production, so that the marginal cost of production is a bad starting point in assessing the revenue of the software (Lippoldt \& Stryszowski, 2009).

Information about innovation indicators received on the basis of CIS questionnaires are valuable for decision-makers both on a national economy level and on management level of innovative enterprises. Decision-makers on a national level can gain a better insight into developing innovative process in an enterprise, as well as the innovating influence on the growth of the economy. Furthermore, items of information obtained in this way are possible to be compared among countries, in addition this enables benchmarking of national economic performances. Information received on the basis of CIS reports can serve to construct different models for assessing innovative enterprise capacity and, lastly, to define recommendations for the enterprise management.

\section{Materials and methods}

Methodology that was used in empirical part of the research is based on European statistical monitoring of innovation activities at the firm level since 1992- Community Innovation Survey (CIS). CIS methodology is based on Oslo manual created by OECD and contributes to better understanding of innovation processes because at the same time it analyzes the impacts of the innovation on the economy: the impact of innovation on competitiveness, employment, economic growth, and society at whole (Mosurović Ružičić, 2012). Having in mind that most of the empirical researches on innovation activities are closely connected to the data obtained by Community Innovation Survey, this paper examines the information obtained for Serbia, regarding the period 2008-2010. 
The survey was conducted on a sample of 3982 firms. Statistical Office of the Republic of Serbia provided the authors with a complete data base (without identification data). This paper further explores connections between numerous CIS questionnaire variables that were not mentioned in the official documents. This enabled a comprehensive analysis of innovation indicators that overcomes the national official reports. The aforementioned data provided the possibility of exploring the type, the scope and the quality of the innovation in two representative sectors: agro-food and software. The aim of the paper is to emphasize the difference between the industries in terms of innovation indicators. The differences are shown through a detailed statistical analysis of the data obtained on a large sample. In addition, the purpose of the obtained results is to be of practical help for decision-makers at the national economy level, as well as at the level of the innovative enterprises in order to improve perspectives of the innovation in Serbian firms. That way, it will be possible to analyze firm's policy towards innovation activities, in terms of informing the companies about the need and effects of innovation, the company's current capacity, and the extent in which some factors accelerate or slow down this type of activity.

For the purposes of the analysis in this paper from the total number of firms, two groups of firms were selected according to NACE classification (NACE Rev. 2): Software industry (SI), 62-64; Agro-food (AF), 10-12. Firms from software and agro-food sectors which have presented technological innovation (product and process innovation) are compared by using: Chi-square test and t- test. The statistical data analysis was done in SPSS program (Statistical Package for the Social Sciences) with intent to determine the (non) existence of statistical differences between firms from software and agrofood sectors, by using Chi-square test and t-test for independent samples, in terms of innovation. This analysis will show in which case there is the statistical difference between observed industries. Frequencies were used for explanation of those differences with aim to determine which industry is more innovative.

\section{Results}

The results of the conducted statistical analyses were presented according to chapters of the CIS questionnaire: Technological innovation (product and process innovation), Innovation activities, Sources of information and co-operation for innovation activities, Innovation objectives, Factors hampering innovation activities.

Technological innovation represent product innovation and process innovation. It can be noticed that firms in both industries were more prone to present a new product than services. But, detailed statistical analysis, conducted by using Chi-square test, indicated a statistically significant difference between software and agro-food sector only in terms of services (in software $47.8 \%$, in agro-food $12 \%$, Table 2.). New goods and services in both observed groups are developed mainly by firms themselves (in software $59.4 \%$, in agro-food 70.6\%, Table 2.). Deeper statistical analysis conducted by using Chi-square test showed that difference between agro-food and software sector was not statistically significant in terms of who developed product innovations (Table 2.). In 
software industry $69.6 \%$ of firms presented technological innovation which was new for their market, while in agro-food sector such innovation was significantly lower, at $29.3 \%$. In terms of innovations that are new only to the firm, the situation turned to be quite the opposite. In agro-food sector, 83.7\% firms presented new goods or services that have already been placed on the market by their competitors, while in software sector there were $64.1 \%$. Detailed statistical analysis conducted by using Chi-square test shows that in both cases there are statistically significant difference in the share of the above types of innovation among the analyzed sectors (Table 2.).

Process innovation is very important for firms due to its impact on reducing production unit costs and the improvement of good/ service quality. Process innovation includes transformation of the technological knowledge into product-related knowledge (Von Tunzelmann, 1995). In the presented research definition from Oslo Manual (OECD, 2005) was used. According to this, process innovation means ,,implementation or adoption of new or significantly improved production or delivery methods. It may involve changes in equipment, human resources, working methods or combination of these (OECD, 2005).

Based on the data analysis in Firms in software sector assessed that the process innovation are a result of supporting activities for process, such as new or significantly improved supporting activities for processes (84.7\%). In agro-food sector, the most important activity of process innovation is new or significantly improved methods of manufacturing or producing goods or services $(85.3 \%$, Table 2.). Detailed statistical analysis, conducted by using Chi-square test indicated a statistically significant difference between observed sectors, in terms of new or significantly improved logistics, delivery or distribution methods, goods or services in favour of agro-food sector, and supporting activities for process, such as new or significantly improved logistics, delivery or distribution methods for inputs, goods or services in favour of software (Table 2.). New processes and products can be introduced as a result of firm's independent and/ or its cooperation with other companies and institutions. The cooperation of the firm with other institutions may be realized as cooperation in the innovation process as well as change and adaptation of process developed by another business entity or institution. In the sector of software the process innovation is developed as a result of joint work of the firm with other firms and/or institutions (84.1\%, Table 2). In the agro-food sector situation is somewhat different, the process innovation was seen to the greatest extent as a consequence of firm's work itself (66.9\%, Table 2). A detailed statistical analysis, conducted by Chi-square test, has shown the existence of statistically significant differences between the observed sectors, depending on the innovator: a firm in cooperation with other firms or institutions; a firm, by adapting or modifying processes originally developed by others; other enterprises or institutions. Detailed statistical analysis by Chi-square test showed that there are statistically significant differences in the share of the process innovation which were new to the market among the analyzed sectors. Process innovations, new to market were, in software sector $46.2 \%$, while in agro-food sector were $25.3 \%$ (Table 2.). 
Table 2. Testing differences in proportion of technological innovation in AF and SI

\begin{tabular}{|c|c|c|c|c|c|c|c|c|}
\hline \multicolumn{2}{|l|}{ Questions } & $\mathbf{M}$ & SI (\%) & $\begin{array}{l}\mathrm{AF} \\
(\%)\end{array}$ & $\chi 2$ - test & (p) & $(\alpha)$ & $\mathbf{R}$ \\
\hline \multirow{4}{*}{$\begin{array}{l}\text { Your firm } \\
\text { introduce: }\end{array}$} & \multirow{2}{*}{$\begin{array}{l}\text { New or significantly } \\
\text { improved goods }\end{array}$} & Yes & 77.6 & 86.9 & \multirow{2}{*}{3.172} & \multirow{2}{*}{0.075} & \multirow{2}{*}{0.05} & \multirow{2}{*}{$=$} \\
\hline & & No & 22.4 & 13.1 & & & & \\
\hline & \multirow{2}{*}{$\begin{array}{l}\text { New or significantly } \\
\text { improved services }\end{array}$} & Yes & 47.8 & 12.0 & \multirow{2}{*}{55.625} & \multirow{2}{*}{0.000} & \multirow{2}{*}{0.05} & \multirow{2}{*}{$\neq$} \\
\hline & & No & 52.2 & 88.0 & & & & \\
\hline \multirow{3}{*}{$\begin{array}{l}\text { Who } \\
\text { developed } \\
\text { product } \\
\text { innovation? }\end{array}$} & \multicolumn{2}{|l|}{ Your firm by itself } & 59.4 & 70.6 & \multirow{3}{*}{3.612} & \multirow{3}{*}{0.164} & \multirow{3}{*}{0.05} & \multirow{3}{*}{$=$} \\
\hline & \multicolumn{2}{|l|}{$\begin{array}{l}\text { Your firm with other firms or } \\
\text { institutions }\end{array}$} & 29.7 & 19.4 & & & & \\
\hline & \multicolumn{2}{|c|}{$\begin{array}{l}\text { Your firm by adapting or modifying } \\
\text { processes originally developed by } \\
\text { other }\end{array}$} & 10.9 & 10.0 & & & & \\
\hline \multirow{4}{*}{$\begin{array}{l}\text { Were any of } \\
\text { your product } \\
\text { innovation? }\end{array}$} & \multirow{2}{*}{ New to your market } & Yes & 69.6 & 29.3 & \multirow{2}{*}{36.673} & \multirow{2}{*}{0.000} & \multirow{2}{*}{0.05} & \multirow{2}{*}{$\neq$} \\
\hline & & No & 30.4 & 70.7 & & & & \\
\hline & \multirow{2}{*}{ New to your firm } & \begin{tabular}{|l|} 
Yes \\
\end{tabular} & 64.1 & 83.7 & \multirow{2}{*}{12.820} & \multirow{2}{*}{0.000} & \multirow{2}{*}{0.05} & \\
\hline & & No & 35.9 & 16.3 & & & & $\neq$ \\
\hline & New or significantly & Yes & 83.4 & 85.3 & & & & \\
\hline & $\begin{array}{l}\text { improved methods of } \\
\text { manufacturing or producing } \\
\text { goods/services }\end{array}$ & No & 16.6 & 14.7 & 0.084 & 0.772 & 0.05 & $=$ \\
\hline Did your firm & New or significantly & Yes & 31.7 & 47.5 & & & & \\
\hline introduce: & $\begin{array}{l}\text { improved logistics, delivery } \\
\text { or distribution methods for } \\
\text { your inputs, goods or services }\end{array}$ & No & 68.3 & 52.5 & 5.719 & 0.017 & 0.05 & $\neq$ \\
\hline & New or significantly & Yes & 84.7 & 67.5 & & & & \\
\hline & $\begin{array}{l}\text { improved supporting } \\
\text { activities for your processes }\end{array}$ & No & 15.3 & 32.5 & 8.949 & 0.003 & 0.05 & $\neq$ \\
\hline & & Yes & 68.1 & 66.9 & 0016 & 0001 & 005 & - \\
\hline & Your firm by itself & No & 31.9 & 33.1 & 0.016 & 0.901 & 0.05 & $=$ \\
\hline & Your firm with other firms or & Yes & 84.1 & 48.5 & 22753 & 0 & 005 & \\
\hline Who & institutions & No & 15.9 & 51.5 & 22.753 & 0 & 0.05 & $\neq$ \\
\hline developed & Your firm by adapting & \begin{tabular}{|l|} 
Yes \\
\end{tabular} & 44.3 & 21.3 & & & & \\
\hline $\begin{array}{l}\text { process } \\
\text { innovation }\end{array}$ & $\begin{array}{l}\text { or modifying processes } \\
\text { originally developed by } \\
\text { others }\end{array}$ & No & 55.7 & 78.7 & 12.784 & 0 & 0.05 & $\neq$ \\
\hline & Other enterprises or & Yes & 16.6 & 14.2 & 104 & 0650 & 005 & $=$ \\
\hline & institutions & No & 83.4 & 85.3 & 0.194 & 0.659 & 0.05 & $=$ \\
\hline Process & Yes & & 46.2 & 25.3 & & & & \\
\hline innovations & \begin{tabular}{|l} 
No \\
\end{tabular} & & 18.6 & 40.7 & 15.946 & 0 & 0.05 & $\neq$ \\
\hline $\begin{array}{l}\text { new to your } \\
\text { market? }\end{array}$ & Don't know & & 35.3 & 34.1 & & & & \\
\hline
\end{tabular}

Source: Authors' calculations, $M$ - modality of the answer, p-realised level of significance, $\alpha$ given level of significance, $R$ - test results

Innovation activities were divided into eight types: in-house $\mathrm{R} \& \mathrm{D}$, external $\mathrm{R} \& \mathrm{D}$, acquisition of machinery, equipment and software, acquisition of external knowledge, training for innovative activities, and market introduction of innovations, design and 
other. These activities can be also observed as investments whose return will be in the future (OECD, 2005). In the software sector the strongest influence on innovation behaviour of the firm was realized by innovation activity- training for innovative activities, and the least effect was associated with external $R \& D$. Firms in agro-food sector usually performed acquisition of machinery, equipment and software and at least in the area of acquisition of external knowledge. It can be seen that in both sectors acquisition of machinery, equipment and software and design were carried out at almost same level of intensity. Data have shown that the intensity of innovation activities is higher in software sector than in agro-food for selected innovation activities: inhouse $R \& D$, external $R \& D$, acquisition of external knowledge, training for innovative activities, market introduction of innovations, and other (Table 3.). There is statistical significance between observed industries.

Table 3. Testing differences in the proportion of innovation activities for AF and SI

\begin{tabular}{|l|l|l|l|l|l|}
\hline \multirow{2}{*}{} & \multicolumn{2}{|c|}{ Frequencies (\%) } & \multicolumn{2}{c|}{ Rang } & \multirow{2}{*}{$\begin{array}{c}\text { Test } \\
\text { results }\end{array}$} \\
\cline { 2 - 5 } & SI & AF & SI & AF & (1) \\
\hline Training for innovative activities & 93,2 & 49 & 1 & 2 & $\neq$ \\
\hline Other & 82,2 & 30 & 2 & 6 & $\neq$ \\
\hline Acquisition of machinery, equipment and software & 73,7 & 75,4 & 3 & 1 & $=$ \\
\hline Market introduction of innovations & 70,6 & 45,8 & 4 & 5 & $\neq$ \\
\hline In-house R\&D & 65 & 49 & 5 & 3 & $\neq$ \\
\hline Acquisition of external knowledge & 56,4 & 14,1 & 6 & 8 & $\neq$ \\
\hline Design & 55,9 & 48,1 & 7 & 4 & $=$ \\
\hline External R\&D & 43 & 25,9 & 8 & 7 & $\neq$ \\
\hline
\end{tabular}

Source: Authors' calculations

Table 4. Testing differences in the proportion of public financial support for innovation activities in SI and AF

\begin{tabular}{|c|c|c|c|c|c|c|c|c|}
\hline & & \multicolumn{2}{|c|}{ Industrial area (\%) } & \multirow{2}{*}{$\chi^{2}$ test } & \multirow{2}{*}{ (p) } & \multirow{2}{*}{ (a) } & \multirow{2}{*}{$\mathbf{R}$} \\
\hline & & & SI & $\mathbf{A F}$ & & & & \\
\hline \multirow{6}{*}{$\begin{array}{l}\text { Did your enterprise } \\
\text { receive any public } \\
\text { financial support } \\
\text { for innovation } \\
\text { activities? }\end{array}$} & \multirow{2}{*}{$\begin{array}{l}\text { Local or regional } \\
\text { authorities }\end{array}$} & Yes & 9.6 & 5.3 & \multirow{2}{*}{2.248} & \multirow{2}{*}{0.134} & \multirow{2}{*}{0.05} & \multirow{2}{*}{$=$} \\
\hline & & $\mathrm{No}$ & 90.4 & 94.7 & & & & \\
\hline & \multirow{2}{*}{ Central government } & Yes & 27.7 & 28.9 & \multirow{2}{*}{0.44} & \multirow{2}{*}{0.833} & \multirow{2}{*}{0.05} & \multirow{2}{*}{$=$} \\
\hline & & No & 72.3 & 71.1 & & & & \\
\hline & \multirow{2}{*}{$\begin{array}{l}\text { European Union } \\
\text { (EU) }\end{array}$} & Yes & 6.1 & 1.00 & \multirow{2}{*}{9.484} & \multirow{2}{*}{0.02} & \multirow{2}{*}{0.05} & \multirow{2}{*}{$\neq$} \\
\hline & & No & 93.9 & 99 & & & & \\
\hline
\end{tabular}

Source: Authors' calculations, ,p-realised level of significance, $\alpha$ - given level of significance, $\mathrm{R}$ - test results

Chi-square test indicated statistically significant difference in terms of receiving financial support for innovation activities from external funds among sectors only in the case of using EU funds in favour of software sector (Table 4.).

On the other hand, there was no statistically significant difference between firms that used support of local or regional authorities as well as central government in 
the observed sectors. It indicates non-discriminatory approach to the availability of financial support, in terms of the sectors mentioned.

Innovation sources are very important for selected firms. The firms, in both observed sectors, ranked information provided within the business entity, as the most important for conducting innovation activities. The reason for concern is the fact that the information received from government or public research institutes was identified as being the least significant. But, the information obtained from the university or other higher education institutions was ranked as extremely important for companies in the agro-food sector, while the firms in software ranked it as irrelevant (Table 6.).

Table 5. Test of Equality of Means values of the importance of each source of information among SI and AF

\begin{tabular}{|c|c|c|c|c|c|c|}
\hline \multicolumn{7}{|c|}{ Independent Samples Test } \\
\hline & & \multicolumn{2}{|c|}{ Levene's Test } & \multicolumn{3}{|c|}{ t-test } \\
\hline & & $\mathbf{F}$ & Sig. & t & df & Sig. \\
\hline \multirow{2}{*}{$\begin{array}{l}\text { Within your enterprise } \\
\text { or enterprise group }\end{array}$} & Equal variances assumed & 68.090 & .000 & -7.456 & 475 & .000 \\
\hline & $\begin{array}{l}\text { Equal variances not } \\
\text { assumed }\end{array}$ & & & -11.951 & 281.059 & .000 \\
\hline \multirow{2}{*}{$\begin{array}{l}\text { Suppliers of equipment, } \\
\text { materials, components }\end{array}$} & Equal variances assumed & 2.973 & .085 & -2.271 & 475 & .024 \\
\hline & $\begin{array}{l}\text { Equal variances not } \\
\text { assumed }\end{array}$ & & & -2.278 & 118.449 & .025 \\
\hline \multirow[b]{2}{*}{ Clients or customers } & Equal variances assumed & .177 & .675 & -2.237 & 475 & .026 \\
\hline & $\begin{array}{l}\text { Equal variances not } \\
\text { assumed }\end{array}$ & & & -2.260 & 119.328 & .026 \\
\hline \multirow{2}{*}{$\begin{array}{l}\text { Competitors or other } \\
\text { enterprises in your } \\
\text { sector }\end{array}$} & Equal variances assumed & 1.953 & .163 & -3.806 & 475 & .000 \\
\hline & $\begin{array}{l}\text { Equal variances not } \\
\text { assumed }\end{array}$ & & & -3.637 & 113.140 & .000 \\
\hline \multirow{2}{*}{$\begin{array}{l}\text { Consultants, } \\
\text { commercial labs, or } \\
\text { private R\&D }\end{array}$} & Equal variances assumed & 2.541 & .112 & -.739 & 475 & .461 \\
\hline & $\begin{array}{l}\text { Equal variances not } \\
\text { assumed }\end{array}$ & & & -.825 & 134.087 & .411 \\
\hline \multirow{2}{*}{$\begin{array}{l}\text { Universities and HE } \\
\text { institutions }\end{array}$} & Equal variances assumed & 2.403 & .122 & .311 & 475 & .756 \\
\hline & $\begin{array}{l}\text { Equal variances not } \\
\text { assumed }\end{array}$ & & & .330 & 125.995 & .742 \\
\hline \multirow{2}{*}{$\begin{array}{l}\text { Government or public } \\
\text { research institutes }\end{array}$} & Equal variances assumed & .001 & .981 & -.450 & 475 & .653 \\
\hline & $\begin{array}{l}\text { Equal variances not } \\
\text { assumed }\end{array}$ & & & -.467 & 122.682 & .641 \\
\hline \multirow{2}{*}{$\begin{array}{l}\text { Conferences, trade } \\
\text { fairs, exhibitions }\end{array}$} & Equal variances assumed & .056 & .813 & -.410 & 475 & .682 \\
\hline & $\begin{array}{l}\text { Equal variances not } \\
\text { assumed }\end{array}$ & & & -.403 & 116.233 & .687 \\
\hline \multirow{2}{*}{$\begin{array}{l}\text { Scientific journals } \\
\text { and trade/technical } \\
\text { publication }\end{array}$} & Equal variances assumed & 4.240 & .040 & -3.590 & 475 & .000 \\
\hline & $\begin{array}{l}\text { Equal variances not } \\
\text { assumed }\end{array}$ & & & -3.708 & 122.147 & .000 \\
\hline
\end{tabular}

Source: Authors' calculations 
Table 6. The importance of sources of information for technological innovation in SI and AF

\begin{tabular}{|l|c|c|c|c|}
\hline \multirow{2}{*}{} & \multicolumn{2}{|c|}{ Software (SI) } & \multicolumn{2}{c|}{ Agro-food (AF) } \\
\cline { 2 - 5 } & Rang & Mean & Rang & Mean \\
\hline Within your enterprise or enterprise group & 1 & 1.21 & 1 & 2.15 \\
\hline Suppliers of equipment, materials, components, or software & 3 & 2.16 & 4 & 2.44 \\
\hline Clients or customers & 2 & 2.13 & 3 & 2.38 \\
\hline Competitors or other enterprises in your sector & 5 & 2.47 & 7 & 2.93 \\
\hline Consultants, commercial labs, or private R\&D & 7 & 2.87 & 8 & 2.97 \\
\hline Universities or other higher education institutions & 9 & 3.38 & 2 & 3.35 \\
\hline Government or public research institutes & 10 & 3.54 & 10 & 3.58 \\
\hline Conferences, trade fairs, exhibitions & 6 & 2.54 & 5 & 2.59 \\
\hline Scientific journals and trade/technical publication & 4 & 2.30 & 6 & 2.72 \\
\hline Professional and industry associations & 8 & 3.12 & 9 & 3.11 \\
\hline
\end{tabular}

Source: Authors' calculations

Table 7.Testing differences in proportion of co-operation for technological innovation

\begin{tabular}{|c|c|c|c|c|c|c|c|}
\hline \multirow[t]{2}{*}{ Questions } & \multirow[t]{2}{*}{ Modality } & \multicolumn{2}{|c|}{$\begin{array}{l}\text { Industrial } \\
\text { area }(\%)\end{array}$} & \multirow[t]{2}{*}{$\chi^{2}$ test } & \multirow[t]{2}{*}{ (p) } & \multirow[t]{2}{*}{ (a) } & \multirow[t]{2}{*}{$\mathbf{R}$} \\
\hline & & SI & $\mathbf{A F}$ & & & & \\
\hline \multirow{2}{*}{$\begin{array}{l}\text { Did your firm co- } \\
\text { operate on any of } \\
\text { innovation activities } \\
\text { with others? }\end{array}$} & Yes & 46.3 & 22.5 & \multirow{2}{*}{19.705} & \multirow{2}{*}{0.000} & \multirow{2}{*}{0.05} & \multirow{2}{*}{$\neq$} \\
\hline & No & 53.7 & 77.5 & & & & \\
\hline \multirow{7}{*}{$\begin{array}{l}\text { Which type of co- } \\
\text { operation partner did } \\
\text { you find the most } \\
\text { valuable for your } \\
\text { firm's innovation } \\
\text { activities? }\end{array}$} & Other firms within your group & 53.7 & 77.5 & \multirow{7}{*}{40.201} & \multirow{7}{*}{0.000} & \multirow{7}{*}{0.05} & \multirow{7}{*}{$\neq$} \\
\hline & $\begin{array}{l}\text { Suppliers of equipment, } \\
\text { materials }\end{array}$ & 13.4 & 2.8 & & & & \\
\hline & Clients or customers & 19.5 & 9.9 & & & & \\
\hline & Competitors or firms in sector & 8.5 & 1.8 & & & & \\
\hline & $\begin{array}{l}\text { Consultants, commercial labs, } \\
\text { or private R\&D }\end{array}$ & $\mathrm{n}<5$ & 2.5 & & & & \\
\hline & Higher education institutions & $\mathrm{n}<5$ & 4.8 & & & & \\
\hline & $\begin{array}{l}\text { Government or public research } \\
\text { institutes }\end{array}$ & $\mathrm{n}<5$ & $\mathrm{n}<5$ & & & & \\
\hline
\end{tabular}

Source: Authors' calculations, $p$-realised level of significance, $\alpha$ - given level of significance, $R$ - test results

Detailed statistical analysis conducted by T-test showed that the difference between agro-food and software sector was statistically significant in terms of some innovation sources. Firms in software sector mostly identified market information (suppliers of equipment, materials, components, or software; clients or customers; competitors; scientific journals and trade/technical publications) as valuable sources for innovation (Table 5.). It is very important to establish cooperation on innovation in order to ensure the smooth flow of information between all actors in national innovation system. This cooperation promotes the sharing and usage of knowledge as between firms themselves 
as well as between firms and research institutions. This collaboration also involves the formatting of closer ties with market sources of information for innovation. The firms in the software sector cooperate with other entities and institutions on innovation activities (46.3\%, Table 7.) to a greater extent than those in agro-food $(22.5 \%$, see Table 7.). Analysis of responses depending on industry activity of the firms, conducted by using Chi-square test, showed that this difference is statistically significant. The highest level of cooperation on innovation activities in both observed sectors was established within the group to which the firm belongs (software sector 53.7\%; agro-food sector 77.5\%, Table 7). Also, the observed firms established cooperation with clients and customers on innovation activities, but significantly less (software sector 19.9\%; agrofood sector $9.9 \%$ ). Detailed statistical analysis conducted by Chi-square test showed the existence of statistically significant differences between the observed sectors.

Cooperation on development of the innovation in technology based industries records increasing tendency. The level of cooperation with other innovation stakeholders is more significant in firms in software than in agro-food (Table 7.). Innovation objectives should be considered in the wider context of the introduction of new products or processes.

Table 8. The importance of objectives for technological innovation in SI and AF

\begin{tabular}{|l|c|c|c|c|}
\hline \multirow{2}{*}{ Objectives for technological innovation } & \multicolumn{2}{|c|}{ Software } & \multicolumn{2}{c|}{ Agro-food } \\
\cline { 2 - 5 } & rang & Mean & rang & Mean \\
\hline Increase range of goods or services & 6 & 2.05 & 2 & 2.25 \\
\hline Replace outdated products or processes & 4 & 1.98 & 3 & 2.44 \\
\hline Enter new markets or increase market share & 3 & 1.89 & 10 & 2.73 \\
\hline Improve quality of goods or services & 1 & 1.52 & 1 & 2.00 \\
\hline Improve flexibility for producing goods or services & 2 & 1.68 & 6 & 2.49 \\
\hline Increase capacity for producing goods or services & 5 & 2.02 & 5 & 2.48 \\
\hline Reduce labor costs per unit output & 7 & 2.24 & 7 & 2.54 \\
\hline Reduce material and energy costs per unit output & 8 & 2.99 & 8 & 2.56 \\
\hline Reduce environmental impacts & 10 & 3.50 & 9 & 2.57 \\
\hline Improve health or safety of your employees & 9 & 3.35 & 4 & 2.46 \\
\hline
\end{tabular}

Source: Authors' calculations

The most significant business objective in agro-food sector was the penetration into new markets, while for the software sector; it was the reduction of harmful environmental impacts (Table 8.). 
Table 9. Test of Equality of Means values of the importance of each objective for technological innovation among SI and AF

\begin{tabular}{|c|c|c|c|c|c|c|}
\hline \multicolumn{7}{|c|}{ Independent Samples Test } \\
\hline & & \multicolumn{2}{|c|}{ Levene's Test } & \multicolumn{3}{|c|}{ t-test } \\
\hline & & $\mathbf{F}$ & Sig. & $\mathbf{t}$ & df & \\
\hline \multirow{2}{*}{$\begin{array}{l}\text { Increase range of goods } \\
\text { or services }\end{array}$} & Equal variances assumed & 4.622 & .032 & -1.551 & 475 & .122 \\
\hline & Equal variances not assumed & & & -1.698 & 130.634 & .092 \\
\hline \multirow{2}{*}{$\begin{array}{l}\text { Replace outdated } \\
\text { products or processes }\end{array}$} & Equal variances assumed & 9.968 & .002 & -3.610 & 475 & .000 \\
\hline & Equal variances not assumed & & & -3.734 & 122.321 & .000 \\
\hline \multirow{2}{*}{$\begin{array}{l}\text { Enter new markets or } \\
\text { increase market share }\end{array}$} & Equal variances assumed & 3.675 & .056 & -6.325 & 475 & .000 \\
\hline & Equal variances not assumed & & & -6.510 & 121.691 & .000 \\
\hline \multirow{2}{*}{$\begin{array}{l}\text { Improve quality of goods } \\
\text { or services }\end{array}$} & Equal variances assumed & .197 & .657 & -3.867 & 475 & .000 \\
\hline & Equal variances not assumed & & & -4.065 & 124.536 & .000 \\
\hline \multirow{2}{*}{$\begin{array}{l}\text { Improve flexibility for } \\
\text { producing goods/services }\end{array}$} & Equal variances assumed & 2.254 & .134 & -6.192 & 475 & .000 \\
\hline & Equal variances not assumed & & & -6.348 & 121.181 & .000 \\
\hline \multirow{2}{*}{$\begin{array}{l}\text { Increase capacity for } \\
\text { producing goods/services }\end{array}$} & Equal variances assumed & 9.542 & .002 & -3.308 & 475 & .001 \\
\hline & Equal variances not assumed & & & -3.548 & 127.447 & .001 \\
\hline \multirow{2}{*}{$\begin{array}{l}\text { Reduce labor costs per } \\
\text { unit output }\end{array}$} & Equal variances assumed & 2.026 & .155 & -2.170 & 475 & .030 \\
\hline & Equal variances not assumed & & & -2.054 & 112.164 & .042 \\
\hline \multirow{2}{*}{$\begin{array}{l}\text { Reduce material and } \\
\text { energy costs/ unit output }\end{array}$} & Equal variances assumed & 1.074 & .301 & 3.208 & 475 & .001 \\
\hline & Equal variances not assumed & & & 2.976 & 110.254 & .004 \\
\hline \multirow{2}{*}{$\begin{array}{l}\text { Reduce material and } \\
\text { energy costs/unit/output }\end{array}$} & Equal variances assumed & 46.063 & .000 & 7.003 & 475 & .000 \\
\hline & Equal variances not assumed & & & 8.856 & 161.751 & .000 \\
\hline \multirow[t]{2}{*}{$\begin{array}{l}\text { Improve health or safety } \\
\text { of your employees }\end{array}$} & Equal variances assumed & 11.936 & .001 & 6.932 & 475 & .000 \\
\hline & Equal variances not assumed & & & 7.745 & 134.063 & .000 \\
\hline
\end{tabular}

Source:Authors' calculations

Detailed statistical analysis conducted by T-test indicated that there were statistically significant differences between the observed sectors regarding almost all objectives of innovation, with the exception of range of goods /services incensement (Table 9.). The high importance of process related objectives was identified in sectors. But, in software sector these objectives were a result of improving flexibility for producing goods or services, while in agro-food sector they were indicated as a result of process innovation. According to the CIS methodology, innovative objectives of the firm are divided into three groups (OECD, 2005): (1)objectives related to the product (increase range of goods or services, replace out-dated products or processes, enter new markets or increase market share, improve quality of goods or services); (2)objectives related to processes (increase production flexibility, increase production capacity, reduced labour costs, reduced material consumption); (3) other objectives (relating to regulations and standards, improve environmental protection or health and safety at work). The observed enterprises have marked the improvement of good/service quality as the most important effect of the technological innovation Table 8.). 
Factors that hamper product and process innovation activities according to CIS are divided into: cost factors, knowledge factors, market factors, and other reasons not to innovate.

Cost factors are related to direct cost of financing innovation activities which are often high. They are closely connected to uncertainty and risk that follow innovation activities. The analysis of responses in on observed sectors, conducted by Chi-square test indicated statistically significant difference in the cost factors in the case of lack of financial resources from its own funds (the highest rank in software $40.9 \%$, the highest rank in agrofood 55.4\%, Table 10.), as well as in the case of direct innovation costs (the highest rank in software $32.6 \%$, the highest rank in agro-food $35.4 \%$, Table 10.) in favour of agro-food sector. On the other hand, there was no statistically significant difference among the firms from observed sectors in terms of lack of funding from outside the firm.

Knowledge factors are closely related to expertise of employees and management. Detailed statistical analysis conducted by using Chi-square test showed that there were statistically significant differences among observed sectors in terms of knowledge factors as limiting factors for innovation activities in these cases: lack of qualified personnel (the highest rank in software 3.2\%, the highest rank in agro-food $9.0 \%$, Table 10.) in favour of agro-food sector; lack of information on technology (the highest rank in software 3.2\%, the highest rank in agro-food $2.8 \%$, Table 10.); more evident in software sector; lack of information on markets (the highest rank in software $2.7 \%$, the highest rank in agro-food 2.8\%, Table 10.); more evident in agro-food sector.

There were no statistical differences among the observed groups of firms regarding difficulties in finding cooperation partners for innovation. Respectively, firms from software sector (11.1\%), as well as, firms from agro-food sector (15.4\%), have marked difficulty to find adequate cooperation partners as important obstacles.

Market factors are determined by market impacts where technology innovations take place.

Table 10. Testing proportion differences in factors that hamper innovation in AF I SI

\begin{tabular}{|c|c|c|c|c|c|c|c|c|c|}
\hline \multirow[b]{2}{*}{ Hampering factors } & & \multicolumn{4}{|c|}{ Modality (\%) } & \multirow[b]{2}{*}{$\chi^{2}$ test } & \multirow[b]{2}{*}{ (p) } & \multirow[b]{2}{*}{ (a) } & \multirow{2}{*}{$\mathbf{R}$} \\
\hline & & high & med & low & $\begin{array}{c}\text { not } \\
\text { expec. }\end{array}$ & & & & \\
\hline \multirow{2}{*}{$\begin{array}{l}\text { Lack of funds within your } \\
\text { enterprise or group }\end{array}$} & SI & 40.9 & 42.7 & 9.8 & 6.6 & \multirow{2}{*}{16.503} & \multirow{2}{*}{0.001} & \multirow{2}{*}{0.05} & \multirow{2}{*}{$\neq$} \\
\hline & $\mathrm{AF}$ & 55.4 & 28.1 & & 13.3 & & & & \\
\hline \multirow{2}{*}{$\begin{array}{l}\text { Lack of finance from sources } \\
\text { outside firm }\end{array}$} & SI & 32.1 & 27.7 & 17.0 & 23.2 & \multirow{2}{*}{1.529} & \multirow{2}{*}{0.676} & \multirow{2}{*}{0.05} & \multirow{2}{*}{$=$} \\
\hline & $\mathrm{AF}$ & 35.4 & 24.2 & 14.4 & 27.0 & & & & \\
\hline \multirow{2}{*}{ Innovation costs too high } & SI & 32.6 & 47.0 & 4.2 & 16.2 & \multirow{2}{*}{10.108} & \multirow{2}{*}{0.018} & \multirow{2}{*}{0.05} & \multirow{2}{*}{$\neq$} \\
\hline & $\mathrm{AF}$ & 47.7 & 33.5 & 8.7 & 10.0 & & & & \\
\hline \multirow{2}{*}{ Lack of qualified personnel } & SI & 3.2 & 23.8 & 43.0 & 30.0 & \multirow{2}{*}{21.273} & \multirow{2}{*}{0.000} & \multirow{2}{*}{0.05} & \multirow{2}{*}{$\neq$} \\
\hline & $\mathrm{AF}$ & 9.0 & 35.8 & 19.3 & 36.0 & & & & \\
\hline \multirow{2}{*}{$\begin{array}{l}\text { Lack of information on } \\
\text { technology }\end{array}$} & SI & 3.2 & 43.4 & 17.4 & 75.0 & \multirow{2}{*}{38.776} & \multirow{2}{*}{0.000} & \multirow{2}{*}{0.05} & \multirow{2}{*}{$\neq$} \\
\hline & $\mathrm{AF}$ & 2.8 & 29.6 & 28.2 & 39.4 & & & & \\
\hline \multirow{2}{*}{$\begin{array}{l}\text { Lack of information on } \\
\text { markets }\end{array}$} & SI & 2.7 & 16.7 & 21.4 & 59.2 & \multirow{2}{*}{20.131} & \multirow{2}{*}{0.000} & \multirow{2}{*}{0.05} & \multirow{2}{*}{$\neq$} \\
\hline & $\mathrm{AF}$ & 2.8 & 19.8 & 43.6 & 33.8 & & & & \\
\hline
\end{tabular}




\begin{tabular}{|c|c|c|c|c|c|c|c|c|c|}
\hline \multirow[b]{2}{*}{ Hampering factors } & & \multicolumn{4}{|c|}{ Modality (\%) } & \multirow[b]{2}{*}{$\chi^{2}$ test } & \multirow[b]{2}{*}{ (p) } & \multirow[b]{2}{*}{ (a) } & \multirow{2}{*}{$\mathbf{R}$} \\
\hline & & high & med & low & $\begin{array}{c}\text { not } \\
\text { expec. }\end{array}$ & & & & \\
\hline \multirow{2}{*}{$\begin{array}{l}\text { Difficulty to find cooperation } \\
\text { partners }\end{array}$} & SI & 11.1 & 30.4 & 13.6 & 45.0 & \multirow{2}{*}{5.062} & \multirow{2}{*}{0.167} & \multirow{2}{*}{0.05} & \multirow{2}{*}{$=$} \\
\hline & $\mathrm{AF}$ & 15.4 & 25.9 & 21.8 & 36.8 & & & & \\
\hline \multirow{2}{*}{$\begin{array}{l}\text { Market dominated by } \\
\text { established firms }\end{array}$} & SI & 25.3 & 41.2 & 25.7 & 7.8 & \multirow{2}{*}{14.012} & \multirow{2}{*}{0.003} & \multirow{2}{*}{0.05} & \multirow{2}{*}{$\neq$} \\
\hline & $\mathrm{AF}$ & 21.1 & 31.1 & 21.6 & 26.2 & & & & \\
\hline \multirow{2}{*}{$\begin{array}{l}\text { Uncertain demand for } \\
\text { innovative products }\end{array}$} & SI & 29.2 & 51.2 & 18.4 & 1.2 & \multirow{2}{*}{23.394} & \multirow{2}{*}{0.000} & \multirow{2}{*}{0.05} & \multirow{2}{*}{$\neq$} \\
\hline & $\mathrm{AF}$ & 16.5 & 40.0 & 23.0 & 20.4 & & & & \\
\hline \multirow{2}{*}{$\begin{array}{l}\text { No need due to prior } \\
\text { innovations by firm }\end{array}$} & SI & 1.7 & 29.5 & 13.7 & 46.8 & \multirow{2}{*}{5.576} & \multirow{2}{*}{0.134} & \multirow{2}{*}{0.05} & \multirow{2}{*}{$=$} \\
\hline & $\mathrm{AF}$ & 5.3 & 21.4 & 26.0 & 47.3 & & & & \\
\hline \multirow{2}{*}{$\begin{array}{l}\text { No need because of no demand } \\
\text { for innovations }\end{array}$} & SI & 10.1 & 29.5 & 13.7 & 46.8 & \multirow{2}{*}{19.498} & \multirow{2}{*}{0.000} & \multirow{2}{*}{0.05} & \multirow{2}{*}{$\neq$} \\
\hline & $\mathrm{AF}$ & 3.3 & 18.5 & 33.5 & 44.6 & & & & \\
\hline
\end{tabular}

Source: Authors' calculations, p-realised level of significance, $\alpha$ - given level of significance, $\mathrm{R}$ - test results

Dipper statistical analysis conducted by Chi-square test eventually indicated statistically significant difference between observed industries in terms of market factors as factors that hampered innovation activities: market dominated by established enterprises (software $25.3 \%$, agro-food $21.1 \%$, Table 10 .); uncertain demand for innovative goods or services (software $29.2 \%$, agro-food 16.5\%, Table 10.). These factors were more important for software sector. Reasons that influence not to innovate are in close relationship with other hampering factors. They depend on market demand as well as the firm's innovation capability. A statistically significant difference was indicated by using Chi-square test, in terms of reasons not to innovate: no need because of any demand for innovations (software 10.1\%, agro-food 3.3\%, Table 10.) in favour of software. This means that the firms involved in software industry respected market's own lack of reason to innovate to a greater extent than the firms involved in agro-food industry did.

\section{Discussions}

A detailed statistical analysis has shown a statistical difference within the agro-food and software firms, concerning certain innovation indicators in the observed period. Innovation activities are more frequent in software than in agro-food sector (Table 11.).

Table 11. Innovation intensity in software vs. agro-food (- higher, ${ }^{-}-$lower)

\begin{tabular}{|l|c|c|c|}
\hline Description & SI & AF & Table \\
\hline New or significantly improved services & & - & 2 \\
\hline Product Innovation- new to your market & & - & 2 \\
\hline Product Innovation- Only new to your firm & - & & 2 \\
\hline New or significantly improved logistics, delivery or distribution methods & - & & 2 \\
\hline $\begin{array}{l}\text { New or significantly improved supporting activities for your } \\
\text { processes, such as maintenance systems, etc. }\end{array}$ & & - & 2 \\
\hline Process innovation development- with other firm or institutions & & - & 2 \\
\hline Process innovation development by adapting & & - & 2 \\
\hline Process innovations introduced new to market? & & - & 2 \\
\hline
\end{tabular}




\begin{tabular}{|c|c|c|c|}
\hline Description & SI & $\mathbf{A F}$ & Table \\
\hline Innovation activities - Training for innovative activities & & & 3 \\
\hline Innovation activities - Other & & & 3 \\
\hline Innovation activities - Market introduction of innovations & & & 3 \\
\hline Innovation activities - In-house $\mathrm{R} \& \mathrm{D}$ & & & 3 \\
\hline Innovation activities - Acquisition of external knowledge & & & 3 \\
\hline Innovation activities - External R\&D & & & 3 \\
\hline Financial support from $E U$ & & & 4 \\
\hline \multicolumn{4}{|l|}{ Sources of information for technological innovation } \\
\hline Within your enterprise or enterprise group & & & 5,6 \\
\hline Suppliers of equipment, materials, components, or software & & & 5,6 \\
\hline Clients or customers & & & 5,6 \\
\hline Competitors or other enterprises in your sector & & & 5,6 \\
\hline Scientific journals and trade/technical publication & & & 5,6 \\
\hline Co-operation on innovation development with firms or institutions & & & 7 \\
\hline Partner- Other enterprises within your enterprise group & & & 7 \\
\hline Partner- Suppliers of equipment, materials, components & & & 7 \\
\hline Partner- Clients or customers & & & 7 \\
\hline Partner- Competitors or other enterprises in your sector & & & 7 \\
\hline Innovation objectives - Replace outdated products or processes & & & 8,9 \\
\hline Innovation objectives - Enter new markets or increase market share & & & 8,9 \\
\hline Innovation objectives - Improve quality of goods or services & & & 8,9 \\
\hline Innovation objectives - Improve flexibility for producing goods or services & & & 8,9 \\
\hline Innovation objectives -Increase capacity for producing goods or services & & & 8,9 \\
\hline Innovation objectives - Reduce labor costs per unit output & & & 8,9 \\
\hline Innovation objectives - Reduce material and energy costs per unit output & & & 8,9 \\
\hline Innovation objectives - Reduce environmental impacts & & & 8,9 \\
\hline Innovation objectives - Improve health or safety of your employees & & & 8,9 \\
\hline Hampering factors- Lack of funds within your enterprise or group & & & 10 \\
\hline Hampering factors - Innovation costs too high & & & 10 \\
\hline Hampering factors - Lack of qualified personnel & & & 10 \\
\hline Hampering factors - Lack of information on technology & & & 10 \\
\hline Hampering factors - Lack of information on markets & & & 10 \\
\hline Hampering factors- Market dominated by established enterprises & & & 10 \\
\hline Hampering factors - Uncertain demand for innovative goods or services & & & 10 \\
\hline Hampering factors - No need because of no demand for innovations & & & 10 \\
\hline
\end{tabular}

Source: Authors' calculations

Technological innovation within the firms in both observed sectors are mainly developed within their own research capacity. Having in mind general characteristics of observed work areas, it was expected that, in comparison to the enterprises in agrofood sector, software industry enterprises have directed their innovative efforts towards development of innovative services. Innovations developed in software sector used to be new for the market, not for the enterprises, while in the agro-food area were mostly incremental and represented a novelty solely to the enterprise itself. However, there is a question of how much the software sector innovations are competitive on an 
international level (e.g. via coordination of innovative product quality with services including standards and procedures which are prescribed by the foreign market). Gaining competitive advantage on an international market is not a small task since all standards relevant to the product quality on an international scale need to be met. Furthermore, it is necessary to thoroughly explore questions concerning intellectual property rights.

Software firms were more interested in developing their innovation through collaboration with other institutions than agro-food companies. That could be a reason why the software firms achieved a better market position in the observed period. Cooperation on innovation development has not yet reached institutional size and is mostly done ad hoc, as necessary, without any specific planned approach. Namely, less than half of the observed enterprises recognized the importance of a cooperation. Partners for cooperating are mostly found in the market. This fact should be used as an advantage, in addition to this; it would be beneficial that the importance of cooperation with academic society be taken into account as well. Cooperation can be facilitated in multiple ways: franchising; mutual investments; different forms of connection between company's business (national and international initiative), procuring new products and processes, sub-negotiating, and cooperation with other stakeholders in the research and development field.

Establishing and improving collaboration on the level of innovation is possible via development of innovative infrastructure, also. This would be a recommendation mainly aimed at governmental institutions, which should support the development of innovative infrastructure that would enable successful transfer of knowledge and technology from faculties and institutes to economy, both on a national and international level. Scientific, research and developmental activities, as a frame of national innovative system, can achieve visible results only if they are globally competitive. Simultaneously, there has to be an efficient system for diffusing results of these activities in the economy, such that cycle duration from the beginning to commercialization of innovation is shortened to the level dictated by the global market. Namely, enterprises must have successful mechanisms of innovation implementation in order to realize them on the market. This process includes systematic problem solving and it works best when there is a clearly defined strategy and system of decision making, which need to help organization to stop or continue progress process (in the event of it going deteriorate).

Innovation in both observed areas turned out to be based mainly on knowledge and firm's individual research and development investments. Some research has shown that there is close connection between technical skills and R\&D cooperation and technological innovation (Leiponen, 2005). Companies in software have shown that education and staff development are important factors for development of innovative enterprises. Only the continuous professional development of employees can improve innovation ability of the firm. Innovation at the firm level among the other factors is determined by formal education, improvement job skills by continuous training, experience, R\&D capacity development and ability to manage technological change (Goedhuys \& Veugelers, 2012).However, the improvement of the innovative capacity of a firm could 
be achieved by training the personnel, providing different levels of specialization. As stated previously, the enterprises of both areas are trying to follow the demands of the market, adjusting their activities accordingly.

The factors, which mostly encumbered performance of innovative activities in both groups of enterprises, are related to lack of financial resources. In observed enterprises in Serbia, financial support of innovative activities is mostly based on central government and very small number of enterprises are requesting a loan to finance solely R\&D activities. In both observed sectors, it is a common practice for the enterprises to expect funding of innovative activities to be provided from national funds (agencies, funds, programs etc.). Since the innovations within agro-food industry has been shown to be far more capital intensive, such enterprises are expected to recognize the direct investment costs as a main limiting factor for innovation. At the other hand, in fast-growing research-intensive industry such as software, there is no strong association between high growth and R\&D cost. Beside R\&D activities, other innovation activities are also important as support to them.

Changes in technology and market demands "are forcing" the innovative enterprises to apply different strategies, exploiting the available resources. The general management position and the "auspicious circumstances" are also the important factors (Freeman, 1982). Innovative enterprise strategy should be an integral part of every enterprise strategy which deals in innovative activities. Nonetheless, under the conditions of transition economy, character of the market itself needs to be investigated since it is evident that a demand for innovative products and services is still a dubious one. Process of innovation and technology diffusion is undergoing constant changes.

Development of a more efficient national innovative system is a necessity for Serbia, if it wants to establish a knowledge-based economy, which is achieved with constant state support. In the areas such as innovative policy, a gap between theory and policy practice should be as smaller as possible. Further development in this area is vital. Development of innovative policy should be molded by practical problems, without researches which are concerned with development of economic theory regarding innovations. Links between innovations and different policies are already recognized in the areas of education, competitiveness, finances, macro-economy, and labor market. Approaches to forming of innovative policy have a tendency to be decided by specific qualities of a country in question, and respond to a unique economic, social and political system of a certain country. However, lately, state and scientists emphasize strongly the trans-national approach and research of "transferable" elements of politics (Holroyd, 2007).

\section{Conclusions}

Primarily, paper stressed out the importance of statistical monitoring of innovative activities through Community Innovation Survey (CIS) of the EUROSTAT. Empirical analysis of data in two observed sectors points out that innovation activities, in Serbia, were more intensive in software sector then in agro-food. In some situation firms from agro-food should follow firms from software in order to improve their innovation 
behaviour: for example, in terms of level of collaboration and connections with other innovation stakeholders; in terms of creation innovation not only for firm but also for the market like firms in software; in terms of professional development, etc. In order to establish final conclusions and recommendations for further work, one should firstly bear in mind the above mention characteristics of the software sector. Secondly, R\&D intensity of agro-food sector should be taken into account and explored further.

On the basis of the research presented in this paper, it is plausible to draw conclusions which are significant to the management of enterprises in observed areas. On the basis of these conclusions, it is possible to provide recommendations for decision-makers in the area of innovative policy:

- Innovation in accordance with requirements of the international market. Gaining competitive advantage on an international market is demanding task since all standards relevant to the product quality on an international scale need to be. The special attention should be put on intellectual property issues.

- Improvement of the collaboration on innovation. The lack of an adequate cooperation between universities and research institutions with the industry should be further analysed.

- Investing in the professional development can improve innovation ability of the firm. Educating and training of employees should be in accordance with the needs of the market, employees and an enterprise. Developed countries increasingly apply the economy growth model based on knowledge.

- Finding financial recourse on the market. There are expectations that financing of innovation activities should be done from national sources by government, in both observed sectors. But firms should consider other sources of funding that can be found on international market (venture capital funds, business angels, international funds). Cooperation with foreign partners, as well as applying for various EU funds supporting innovative activities should also be taken into consideration.

- Strategic approach for managing innovation on a national and entrepreneurial level is needed. Data gained on the basis of CIS surveys enable insight into indicators that determine innovative capacity of an enterprise, which is significant for the management of innovative enterprises. The empirical research of innovative activities in Serbia within the observed sectors shows the necessity of a serious analytic framework guiding the industrial policy creators in order to develop general and strengthen institutional, economical and technological factors for improving the competitiveness in agro-food and software industries, as well as the industry as a whole, which is necessary if a more efficient entrance in the world market is sought. For the creators of industrial policies, the research can be useful for forming a new industrial policy model, since managing modern economy and channelling changes of 
economy structure, especially under conditions of transitional economy, is no longer possible without achieving consistent innovative policy. According to these recommendations, the innovative enterprises management could respond to problems in business economy through the field of innovation management, and formulate adequate business strategies.

The presented research has opened up some topics that could be explored further. Primarily, high technologies have enabled the revitalization of traditional manufacturing industries, as well as economic re-industrialization of developed countries. Firm's productivity - both in agro-food and software sector - turned out to be highly dependent on the application of innovations that were developed in other industrial sectors. In connection to that, a further research should be conducted in order to explore the impact of software on agro-food. Secondly, technological innovations were so far mostly presented within the national market. It's highly recommended for firms in both sectors to present their technological innovation to foreign markets. Finally, it would be more than useful - concerning cooperation on innovation in software sectors - to explore types and levels of cooperation in order to achieve further improvement.

\section{Acknowledgements}

Paper is a part of research within the projects no. III 47005- Research and Development of the Platform for Science Based Management of the Scientific and Technological Development of the Republic of Serbia and TR 36005- New technologies in intelligent transportation systems - application in urban and suburban areas, financed by the Ministry of Education, Science and Technological Development of the Republic of Serbia. Project period: 2011-2018.

\section{Conflict of interests}

The authors declare no conflict of interest.

\section{References}

1. Adenle, A.A., Manning, L., \& Azadi, H. (2017). Agribusiness innovation: A pathway to sustainable economic growth in Africa. Trends in Food Science \& Technology 59, 88-104.

2. Aralica, Z., Račić, D., \& Radić, D. (2008). Innovation propensity in Croatian Enterprises: Results of the Community Innovation Survey, South East European Journal of Economics and Business 3(1), 77-88, DOI: 10.2478/v10033-008-0008-6.

3. Cassiman, B., \& Veugelers, R. (2002). R\&D Coperation and Spillovers: Some Empiraical Evidence from Belgium, The American Economic Review 92 (4), 1169 1184. 
4. Copus, A., Skuras, D., \& Tsegendi, K. (2008). An Empirical Comparative Study of SMEs in Six European Union Member Countries, Economic Geography 84 (1), 51-82.

5. Dosi, G. (1988). The nature of innovative process. In Technical Change and Economic theory, Dosi, G. et al.eds., Pinter Publishing Limited. London, UK . 221- 239.

6. Drucker, P. (2003). The Essential Drucker, Novi Sad: Adižes.

7. Franconi, L., \& Stander, J. (2002). A model-based method for disclosure limitation of business microdata, The Statistician, 51(1), 51-61.

8. Goedhuys, M., \& Veugelers, R. (2012). Innovation strategies, process and product innovations and growth: Firm-level evidence from Brazil, Structural Change and Economic Dynamics, 23, 516- 529.

9. Gotz, M. (2015). Innovations in Solving Eurozone Crisis: Review of Some Unconventional Proposals, Transformations in Business \& Economics, 14 (34), 161-173.

10. Freeman, C. (1982). The Economics of Industrial Innovation, Cambridge: The MIT Press.

11. Jović, Z., Vićentijević, K., \& Glišović, N. (2016). Sustainable growth rate of agricultural and food enterprises in Serbia, Economics of Agriculture, 63, 9-29.

12. Knell, M. (2008). Product-embodied technology diffusion and intersectorial linkage in Europe, Europe INNOVA Sectorial Watch deliverable WP4, Brussels: European Commission.

13. Živković, L., Kutlača, Dj., Kleibrink A., \& Štrbac, D. (2018). Characteristics of the Software Industry in Serbia, Ekonomika preduzeća, 3-4, 226-235.

14. Holroyd, C. (2007). Science and Technology Policies, National Competitiveness and the Innovation Divide, Working Paper No.32, The Centre for International Governance Innovation, Retrieved from www.cigionline.org, (July 2017)

15. Leiponen, A. (2005). Skills and Innovation, International Journal of Industrial Organisation, 23, 303-323.

16. Lippoldt, D., \& Stryszowski, P. (2009). Innovation in the software sector, OECD Publishing, accessed through OECD online bookshop, Retrieved from http:/www. oecdbookshop.org, (June 2017).

17. Lundvall, B-A. (1988). Technical Change and Economic theory: Innovation as one interactive process: from user-producer perspectives to the national system of Innovation London, UK : Pinter Publishing Limited, 349- 370.

18. Lundvall, B., Johnson, B., Anderson, S. E., \& Balum, B. (2002). National systems of production, innovation and competence building, Research Policy, 31 , 213-231.

19. Mairesse, J., Mohnen, P., \& Kremp, E. (2005). The importance of R\&D and Innovation for Productivity: A Re-examination in Light of the French Innovation Survey, Annales d'Économie et de Statistique, 79/80, 487-527. 
20. Mosurović, M., \& Kutlača Dj. (2011).Organizational design as a driver for firm innovativeness in Serbia, Innovation: The European Journal of Social Science Research, 24, No. (4), 427-447, http://dx.doi.org/10.1080/13511610.2011.63343 2, 2011

21. Mulder, M. (2008). From Tradition to Innovation. Skill Needs in the Agri-Food Sector-homepage, Retrieved from http://www.mmulder.nl, (June, 2013).

22. Negassi, S. (2004). R\&D co-operation and Innovation in microeconomic study on French firms, Research Policy 33, 365-384. DOI:10.1080/13511610.2011.633432,

23. OECD (2005). Oslo Manual, $3^{\text {th }}$ edition, Paris.

24. Statistical Office of the Republic of Serbia (2017). Indicators of Innovative Activities in the Republic of Serbia, 2014-2016, Release number 197.

25. Statistical Office of the Republic of Serbia (2015). Indicators of Innovative Activities in the Republic of Serbia, 2012-2014, Release number 276.

26. Statistical Office of the Republic of Serbia (2013). Indicators of Innovative Activities in the Republic of Serbia, 2010-2012, Release number 285.

27. Statistical Office of the Republic of Serbia (2011). Indicators of Innovative Activities in the Republic of Serbia, 2008-2010, Release number 347.

28. Sternberg, R., Arndt, O. (2001). What Determines the Innovation Behaviour of European Firms?, Economic Geography 77 (4), 364-382.

29. Mosurović Ružičić, M. (2012). Organisation and innovation, Editor: Institut Mihajlo Pupin, Beograd

30. Von Tunzelmann, G.N. (1995). Technology and Industrial Progress: The Foundations of Economic Growth, Edward Elgar Publishing Limited, UK. 